\title{
Abnormalities in endocrine and immune cells are correlated in dextran-sulfate-sodium-induced colitis in rats
}

\author{
MAGDY EL-SALHY ${ }^{1-3}$, JAN GUNNAR HATLEBAKK ${ }^{2,3}$ and ODD HELGE GILJA ${ }^{2-4}$ \\ ${ }^{1}$ Division of Gastroenterology, Department of Medicine, Stord Hospital, 5416 Stord; \\ ${ }^{2}$ Division of Gastroenterology, Department of Clinical Medicine, University of Bergen, 5020 Bergen; \\ ${ }^{3}$ National Centre for Functional Gastrointestinal Disorders; ${ }^{4}$ National Centre for Ultrasound in Gastroenterology, \\ Department of Medicine, Haukeland University Hospital, 5021 Bergen, Norway
}

Received July 13, 2016; Accepted October 25, 2016

DOI: $10.3892 / \mathrm{mmr} .2016 .6023$

\begin{abstract}
The interaction between the gut hormones and the immune system has been suggested to serve an important role in the pathophysiology of inflammatory bowel disease. The aims of the present study were to elucidate the possible abnormalities in the colonic endocrine cells in rats with dextran sodium sulfate (DSS)-induced colitis, and to determine whether they are correlated with alterations in the immune cells. A total of 24 male Wistar rats were divided into two groups: Control and DSS-induced colitis. Colonic tissues were harvested via postmortem laparotomy from all of the animals at the end of the experimental period, and fixed and sectioned for histology. The colonic endocrine and immune cells in those tissue samples were immunostained and their densities quantified by computerized image analysis. The densities of chromogranin A, serotonin, peptide YY and oxyntomodulin cells were significantly higher, and those of pancreatic peptide and somatostatin cells were lower in rats with DSS-induced colitis than in the controls. The densities of mucosal leukocytes, $\mathrm{T}$ and $\mathrm{B}$ lymphocytes, macrophages/monocytes, and mast cells were significantly higher than in the controls, and these changes were closely associated with the aforementioned changes in all endocrine cell types. These observations indicate an interaction between intestinal hormones and the immune system as represented by immune cells.
\end{abstract}

\section{Introduction}

The etiology of inflammatory bowel disease (IBD) remains unclear (1-3). There are three main forms of IBD, ulcerative colitis (UC), Crohn's disease (CD) and microscopic colitis

Correspondence to: Professor Magdy El-Salhy, Division for Gastroenterology, Department of Medicine, Stord Hospital, Box 4000, 5409 Stord, Norway

E-mail: magdy.el-salhy@helse-fonna.no

Key words: DSS colitis, chromogranin A, endocrine cells, immune cells, serotonin, PYY
(MC), which exhibit differences in prevalence, clinical course and prognosis (3-6). While the onset of UC and CD occurs predominantly in individuals $<40$ years, the onset of $\mathrm{MC}$ occurs in those $>60$ years $(3,7)$. In addition to the morbidity caused by IBD, it considerably reduces the quality of life of patients $(3,5,6)$.

The gastrointestinal endocrine cells are a component of the local regulatory system of the gut, the neuroendocrine system (NES) (8), which also includes the enteric nervous system (8). The NES regulates gastrointestinal motility, secretion, absorption, cell proliferation, visceral sensitivity, local immune defense and appetite $(8,9)$. Abnormalities in several intestinal endocrine cells have been reported in IBD (10-29). It is believed that the interaction between the hormones secreted by the gut endocrine cells and the immune system serve a major role in the pathophysiology of the IBD $(30,31)$.

The primary aim of the present study was to establish the presence of abnormalities in the colonic endocrine cells following dextran sulfate sodium (DSS)-induced colitis in rats, which closely mimics human UC (32). Furthermore, the existence of a correlation between any colonic endocrine cell abnormalities and changes in the densities of various types of immune cells was determined.

\section{Materials and methods}

Rats. A total 24 male Wistar rats (age, 12 weeks; Hannover GALAS; Taconic Biosciences, Lille Skensved, Denmark) with a mean body weight of $280 \mathrm{~g}$ (range, 231-380 g) were housed in Macrolon III cages with water and food available ad libitum. They were fed a standard diet (B \& K Universal, Nittedal, Norway) consisting of cereal products $(88.5 \%)$, soy protein $(6 \%)$, animal protein $(2.5 \%)$, soy oil $(0.5 \%)$, and vitamin, mineral and amino-acid supplements $(2.5 \%)$. The animals were maintained at a temperature of $21 \pm 1^{\circ} \mathrm{C}$ and a relative humidity of $55 \pm 5 \%$, and under a $12 / 12$-h light/dark cycle.

The animals were left to acclimatize in the animal house for 7 days prior to the experiment, and were then divided into 2 groups of 12 animals each: Control and DDS-induced colitis (DSS group). Animals in the control group were provided with normal drinking water for 7 days, while those in the 

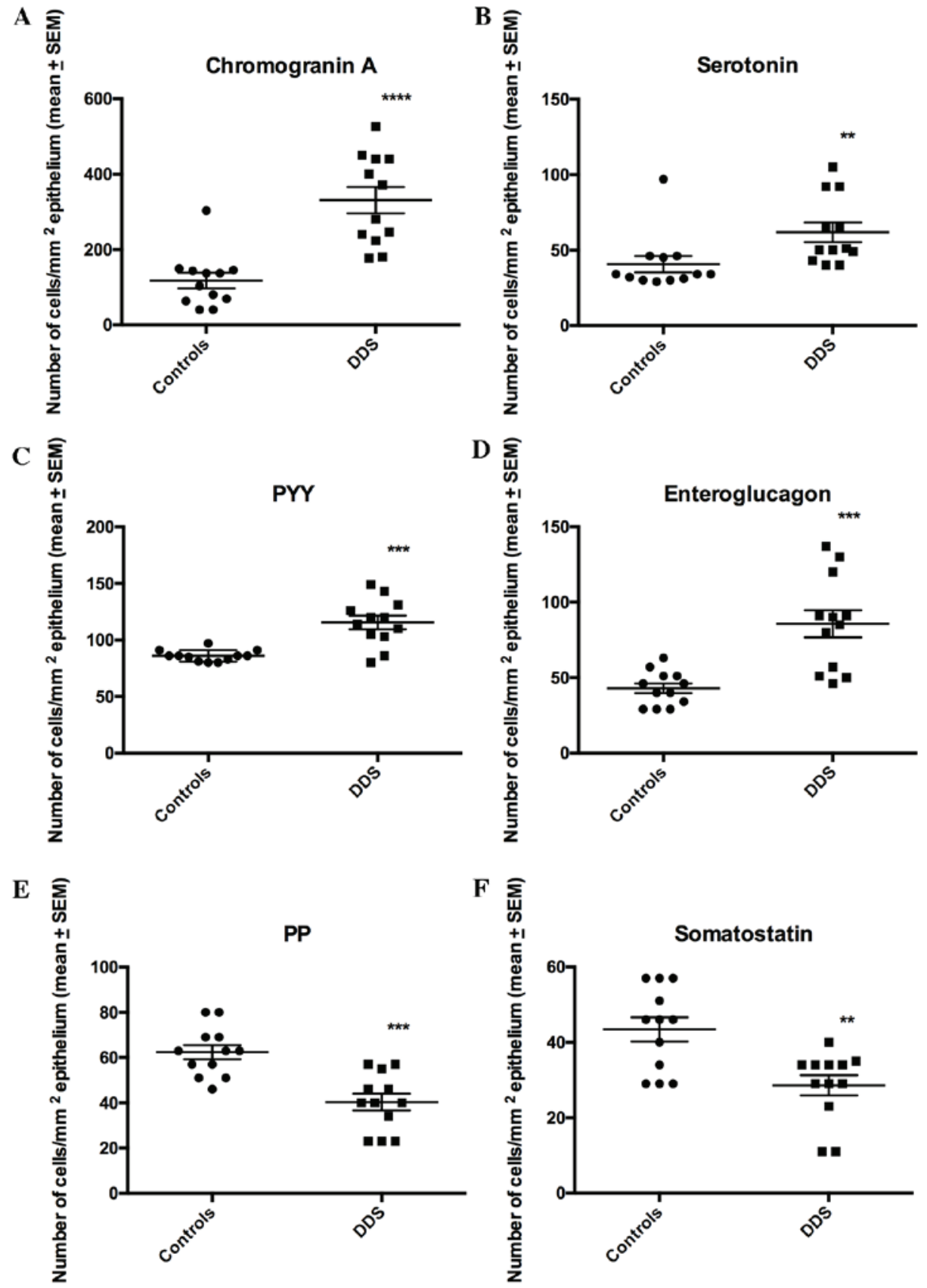

Figure 1. Densities of various endocrine cell types: (A) Chromogranin A; (B) serotonin; (C) PYY; (D) enteroglucan; (E) PP and (F) somatostatin, in the controls and in rats with DSS-induced colitis. ${ }^{* *} \mathrm{P}<0.01,{ }^{* * *} \mathrm{P}<0.001,{ }^{* * * * *} \mathrm{P}<0.0001$ vs. controls. DSS, dextran-sulfate-sodium; SEM, standard error of the mean; PP, pancreatic peptide; PYY, peptide YY.

DDS-colitis group were instead provided with distilled water containing 5\% DSS (molecular weight, $40 \mathrm{kDa}$; prepared daily; TdB Consultancy AB, Uppsala, Sweden) for 7 days, according to a previously described protocol $(33,34)$. All of the animals were monitored twice daily and were weighed once daily. Animals that showed any signs of pain were given a subcutaneous, $1 \mathrm{ml}$ injection of Temgesic solution (containing $0.3 \mathrm{~g} / \mathrm{ml}$ Temgesic; Merck Millipore, Darmstadt, Germany).

At the end of the 7-day period, the animals were sacrificed by $\mathrm{CO}_{2}$ inhalation, and the colon was dissected out via a postmortem laparotomy. Tissue samples were collected from the lower part of the colon for further, histopathological and immunohistochemical examinations.
The local ethical committee for the Protection of Vertebrate Animals used for Experimental and Other Scientific Purposes approved the study protocols (project no. 20124629).

Histopathology and immunohistochemistry. The tissue samples were fixed overnight in $4 \%$ buffered paraformaldehyde, embedded in paraffin and then sectioned at a thickness of $5 \mathrm{~mm}$. The sections were deparaffinized and then stained with hematoxylin-eosin, or immunostained using the ultraView Universal DAB Detection kit (version 1.02.0018, Ventana Medical Systems, Inc., Basel, Switzerland) and the BenchMark Ultra IHC/ISH staining module (Ventana Medical Systems, Inc.). 
A

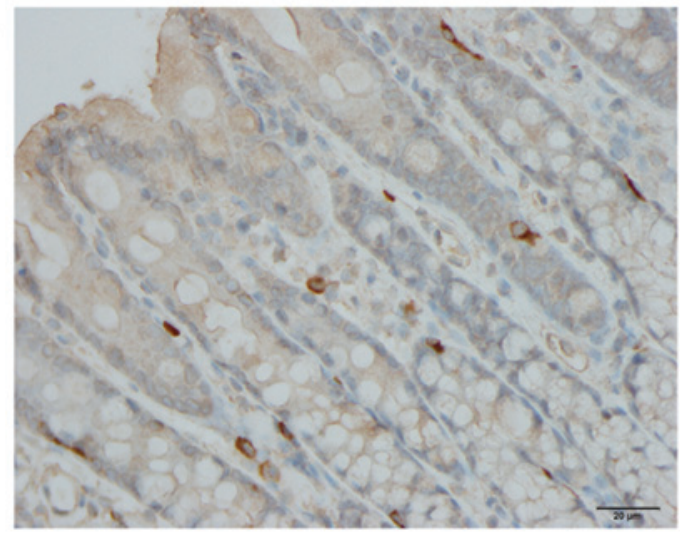

B

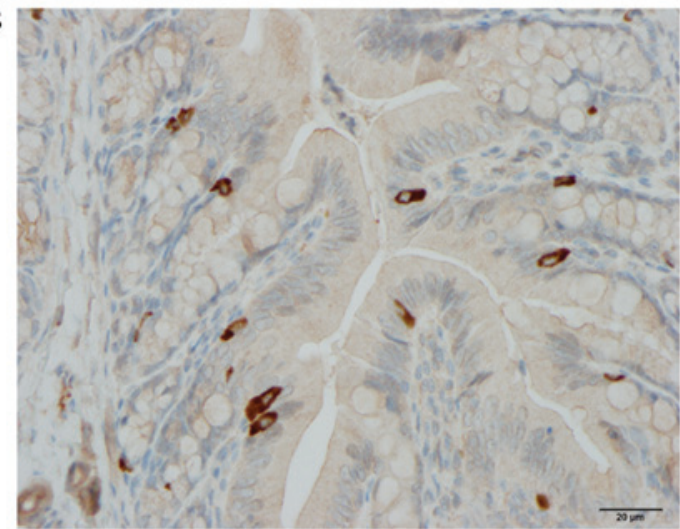

Figure 2. Chromogranin A (CgA)-immunoreactive-cells in (A) a control and in (B) a rat with DSS-induced colitis.

A

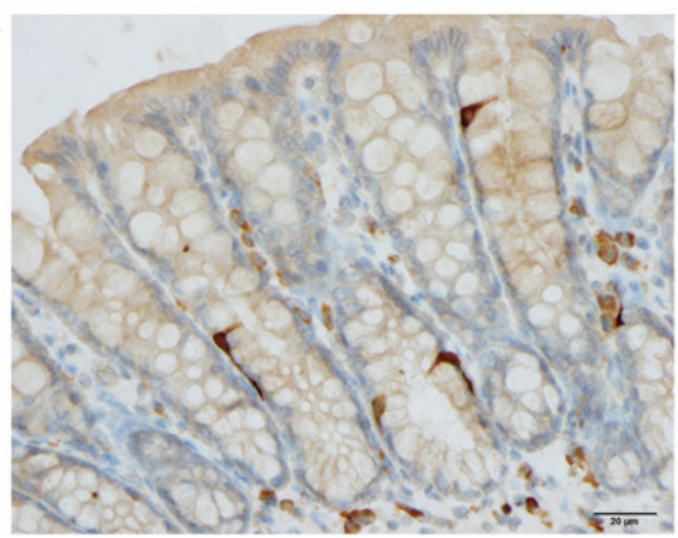

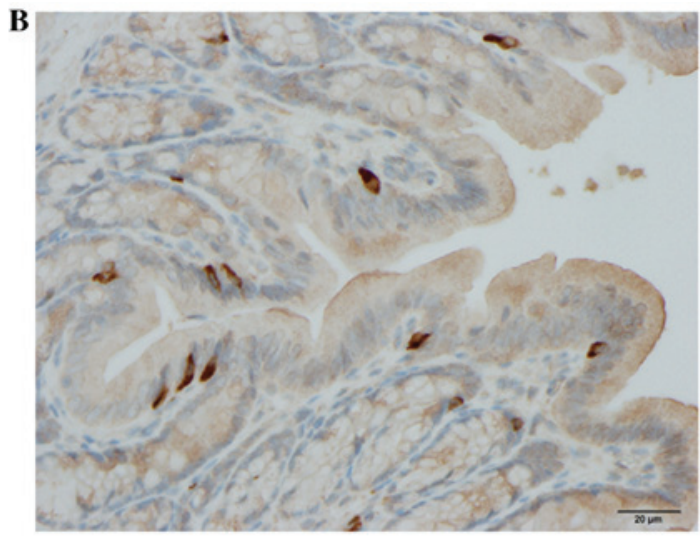

Figure 3. Peptide YY cells in (A) a control rat and (B) in a rat with DSS-induced colitis.
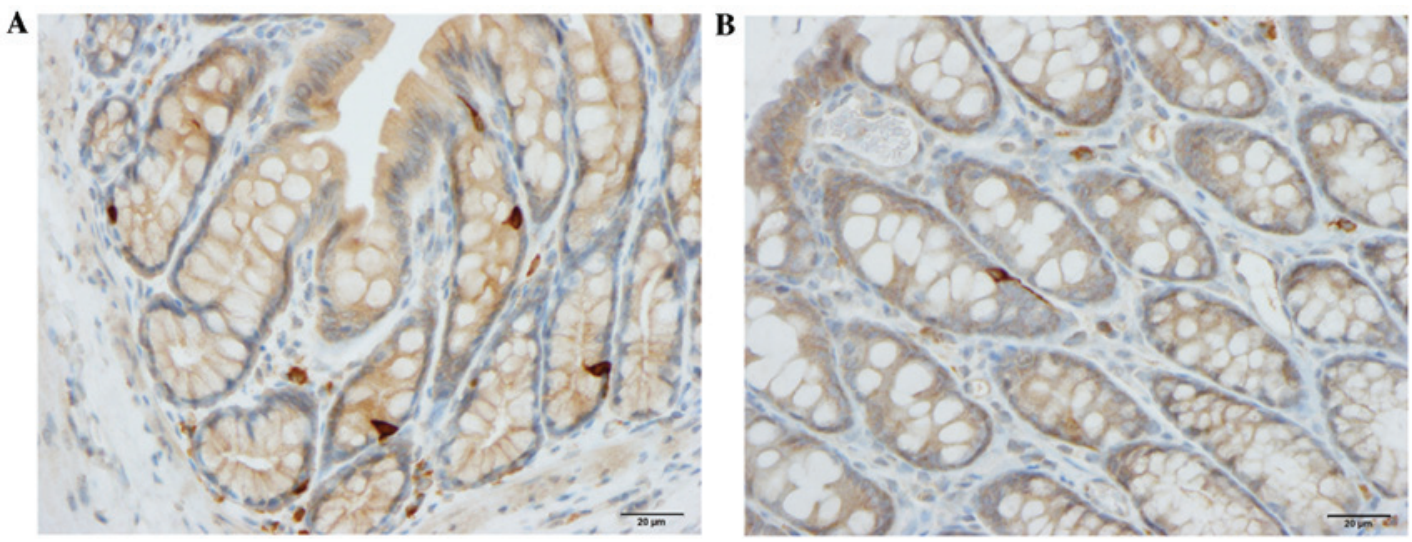

Figure 4. Somatostatin cells in the colon of (A) a control rat, and (B) in a rat with DSS-induced colitis.

For immunostaining, the sections were incubated with one of the following primary antibodies for $32 \mathrm{~min}$ at $37^{\circ} \mathrm{C}$ : Monoclonal mouse anti-N-terminal of purified chromogranin A (CgA; cat. no. M869; Dako, Glostrup, Denmark) diluted 1:1,000, monoclonal mouse antiserotonin (cat. no. 5HT-209; Dako) diluted 1:1,200, polyclonal antiporcine peptide YY (PYY; cat. no. PYY 11A; Alpha Diagnostic International, San Antonio, TX, USA) diluted 1:1,400, polyclonal rabbit antisynthetic human pancreatic polypeptide (PP; cat. no. \#114; Diagnostic BioSystems, Pleasanton, CA, USA) diluted 1:800, polyclonal rabbit antiporcine oxyntomodulin 'glicentin/enteroglucagon' (cat. no. BP508; Acris Antibodies $\mathrm{GmbH}$, Herford, Germany) diluted 1:400, polyclonal rabbit antisynthetic human somatostatin (cat. no. A566; Dako) diluted 1:200, monoclonal mouse antihuman CD45 (cat. no. M0701; Dako) diluted 1:100, monoclonal mouse antihuman CD5 (cat. no. IS082; Dako) diluted 1:200, monoclonal mouse antihuman CD57 (cat. no. IS647; Dako) diluted 1:100, monoclonal mouse antihuman CD23 (cat. no. IS781; Dako) diluted 1:100, monoclonal mouse antihuman CD68 (cat. no. M0814; Dako) diluted 

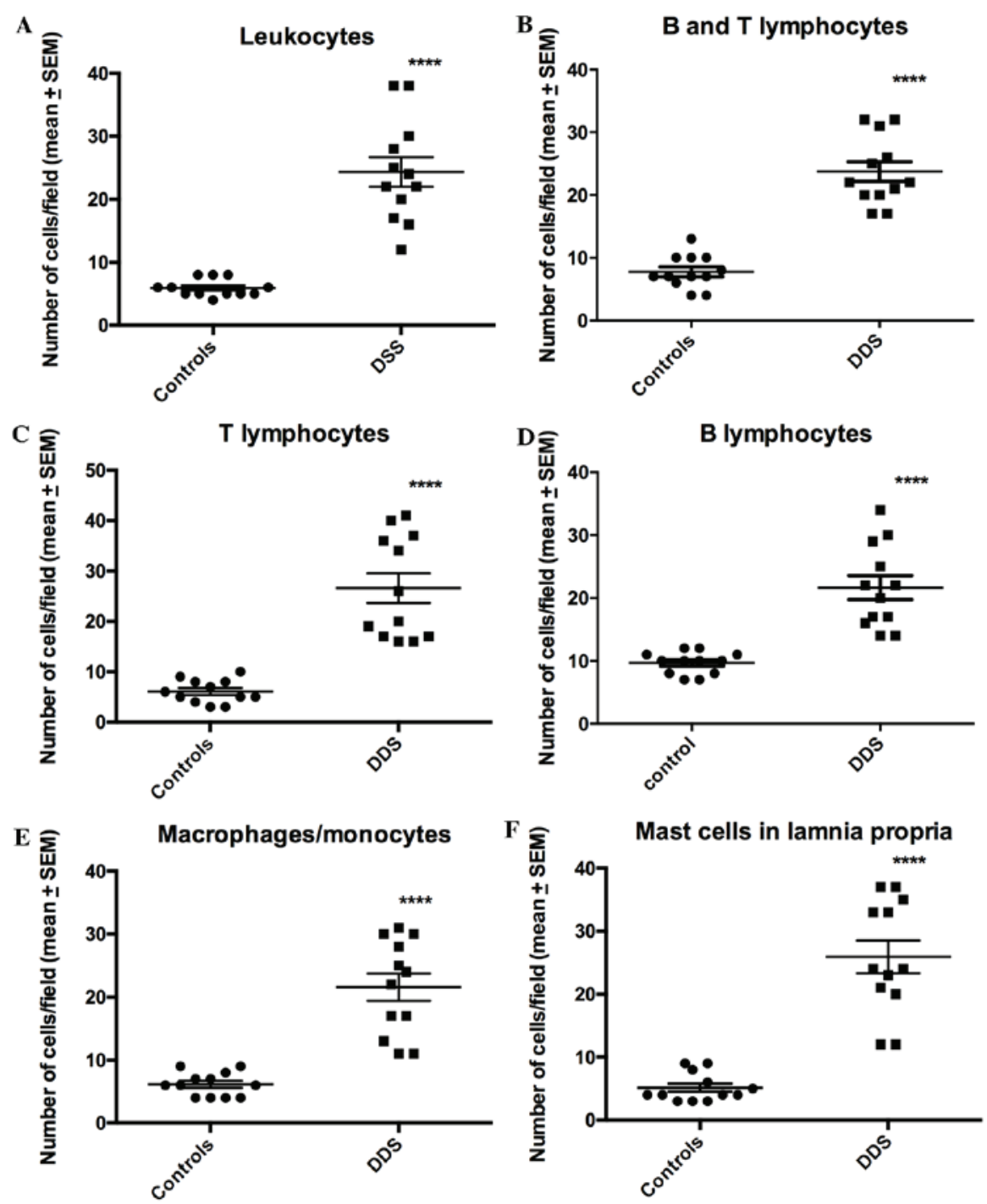

Figure 5. Densities of different types of immune cells: (A) Leukocytes; (B) B and T lymphocytes; (C) T lymphocytes; (D) B lymphocytes; (E) macrophages/monocytes and (F) mast cells in the lamina propria of control rats and rats with DSS-induced colitis. ${ }^{* * * * *} \mathrm{P}<0.0001$ vs. controls. DSS, dextran-sulfate-sodium.

1:100 and monoclonal mouse antihuman mast-cell tryptase (cat. no. M7052; Dako) diluted 1:100. CD45 is considered a common leukocyte antigen and is expressed exclusively on cells of the hematopoietic system and their progenitors. CD5 is expressed on B and T lymphocytes, CD57 is expressed by subsets of natural killer cells and $\mathrm{CD} 8^{+}$lymphocytes, and by a small proportion of $\mathrm{CD}^{+} / \mathrm{CD} 45 \mathrm{R} 0^{+} \mathrm{T}$ lymphocytes, $\mathrm{CD} 23$ is expressed on B lymphocytes, CD68 labels human monocytes, macrophages, and myeloid cells, and mast-cell tryptase is expressed predominantly in mast cells (35).

Quantification of endocrine and immune cells. The endocrine and immune cells were quantified by counting each cell type in 10 randomly chosen microscopic fields. Measurements were performed on a computer linked to a microscope (BX43; Olympus Corporation, Tokyo, Japan) that was equipped with a digital camera (DP26; Olympus Corporation), and using cellSens imaging software (version 1.7; Olympus Corporation). The number of endocrine cells in the epithelial lining of the intestinal lumen and immune cells in the lamina propria of each field were counted on a computer screen, and the area of the epithelial cells was determined by manual drawing using the computer mouse. A 40X objective was used, for which each frame (field) on the monitor represented a tissue area of $0.035 \mathrm{~mm}^{2}$. The data are presented as density measurements (i.e., the number of endocrine cells $/ \mathrm{mm}^{2}$ epithelium, and the number of immune cells per field). Immunostained sections were coded and mixed, and measurements were made by the same person (Professor Magdy El-Salhy), who was blind to the identity of the sections.

Statistical analysis. Differences between the control and DSS groups were tested using the Mann-Whitney nonparametric test. The existence of a correlation between abnormalities/alterations in the densities of endocrine cells and immune cells was determined using the nonparametric Spearman's correlation test. The data are presented as the mean \pm standard error, and $\mathrm{P}<0.05$ was considered to indicate a statistically significant difference.

\section{Results}

The histopathological examinations of the colonic tissues produced normal results in the control group, whereas the DSS 

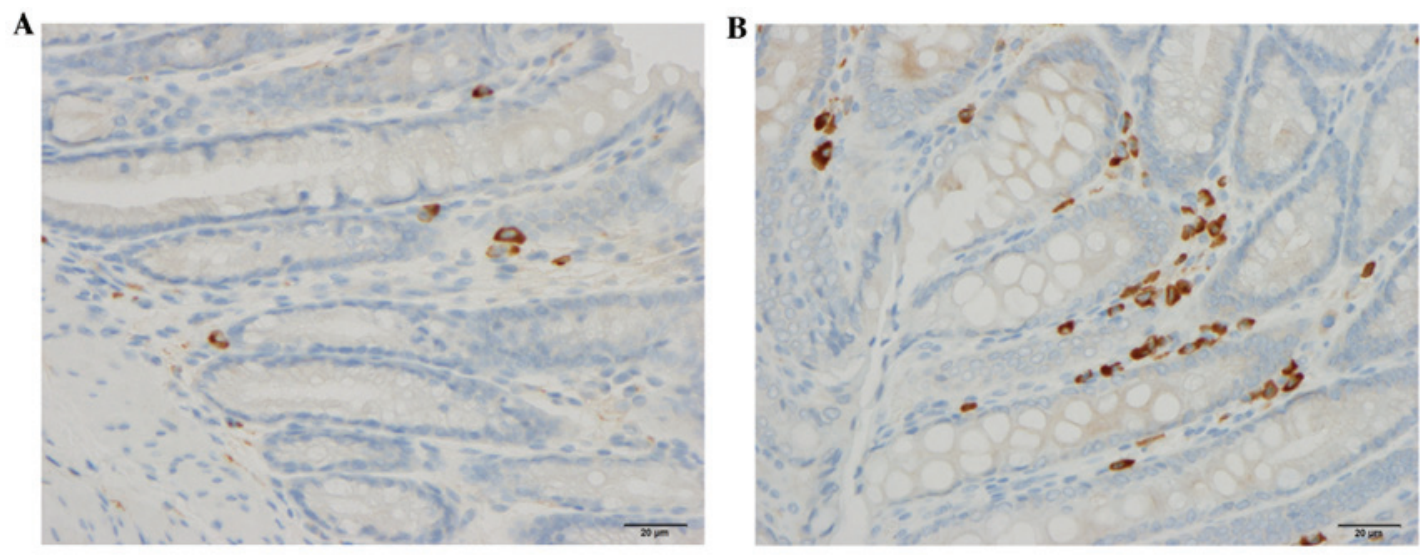

Figure 6. Submucosal leukocytes in (A) a control rat and (B) in a rat with DSS-induced colitis.
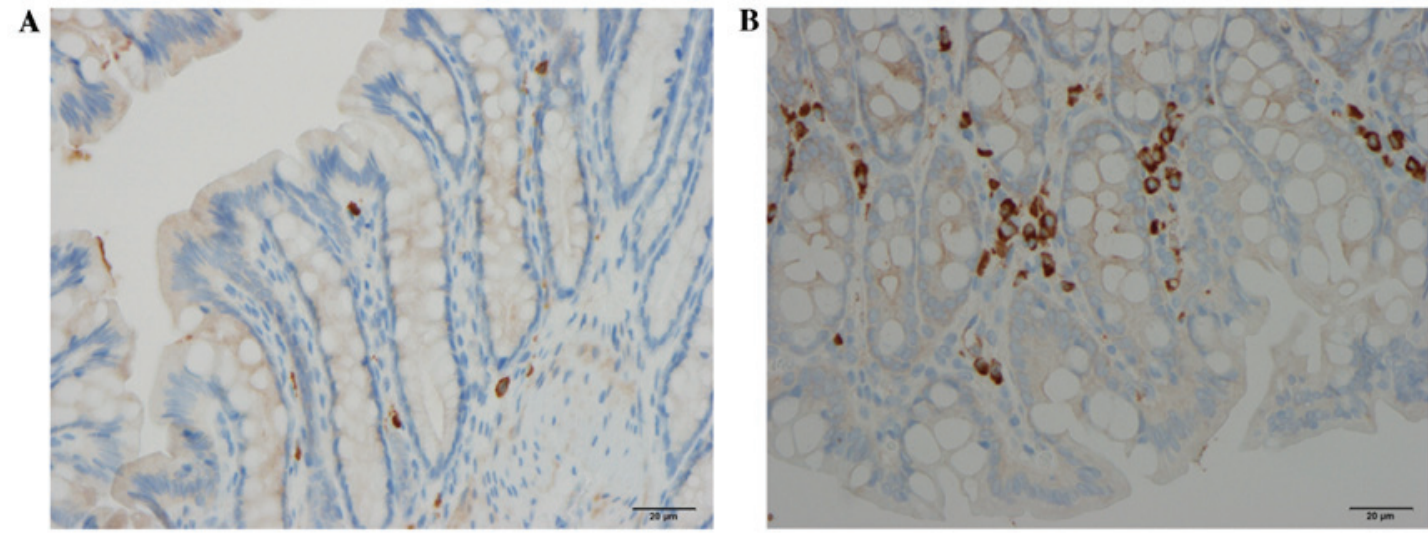

Figure 7. B/T lymphocytes in the submucosa of (A) a control rat and in (B) a rat with DSS-induced colitis.
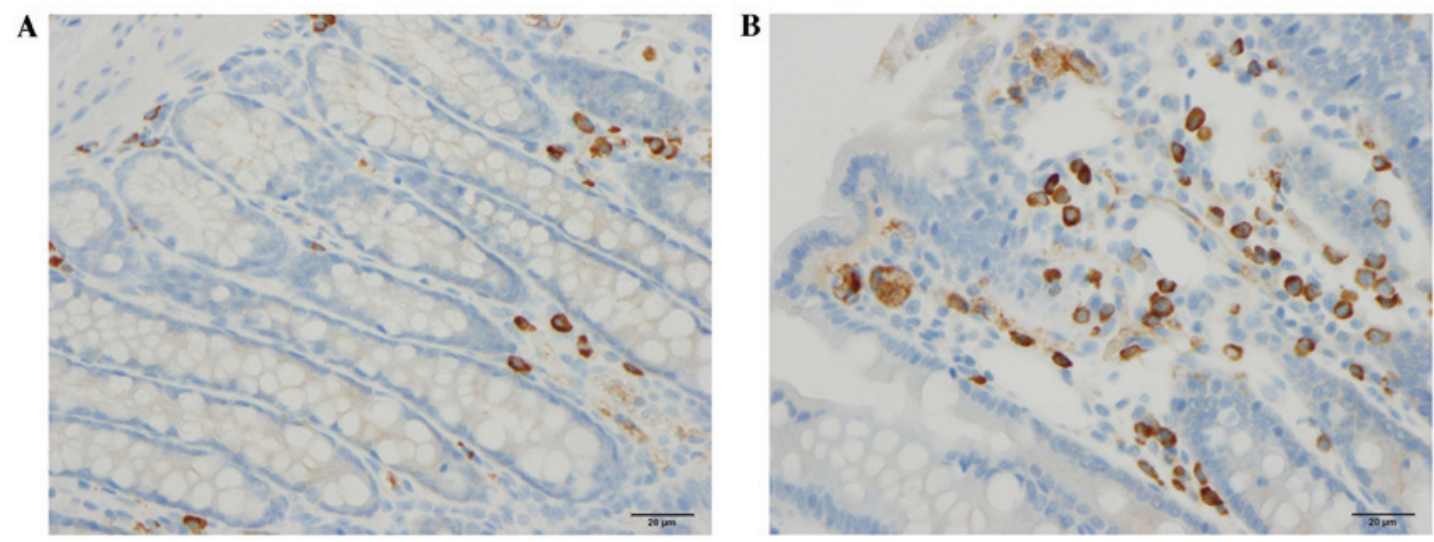

Figure 8. Submucosal mast cells in (A) a control rat and in (B) a rat with DSS-induced colitis.

group had severe-to-moderate inflammation with disturbed mucosal architecture, crypt abscesses, edema, bleeding and infiltration of immune cells into the mucosa and submucosa.

Endocrine cells. The densities of CgA, serotonin, PYY and enteroglucagon cells were all significantly higher in the DDS group $\left(333.1 \pm 34.7,61.8 \pm 6.5,115.6 \pm 5.9\right.$ and $85.7 \pm 9.0$ cells $/ \mathrm{mm}^{2}$ epithelium, respectively) than in the control group $(117.4 \pm 20.7$, $40.7 \pm 5.5,86.0 \pm 1.5$ and $42.9 \pm 3.3$ cells $/ \mathrm{mm}^{2}$ epithelium;
$\mathrm{P}<0.0001, \mathrm{P}=0.0006, \mathrm{P}=0.002$ and $\mathrm{P}=0.0003$, respectively; Figs. 1-3). Conversely, the densities of PP and somatostatin cells were significantly higher in the control group $(62.4 \pm 3.1$ and $43.4 \pm 3.2$ cells $/ \mathrm{mm}^{2}$ epithelium, respectively) than in the DSS group $\left(40.3 \pm 3.7\right.$ and $28.6 \pm 2.7$ cells $/ \mathrm{mm}^{2}$ epithelium, respectively; $\mathrm{P}=0.0002$ and 0.007, respectively; Figs. 1 and 4).

Immune cells. The densities of all of the immune cell types were significantly higher in the DDS group than 
Table I. Summary of the Spearman correlation coefficient $(r)$ and $\mathrm{P}$ values between different endocrine cell types and various immune cells.

Immune cell type

\begin{tabular}{lcccccc}
\cline { 2 - 6 } Endocrine cell type & Leukocytes & $\mathrm{B}$ / T lymphocytes & T lymphocytes & B lymphocytes & $\begin{array}{c}\text { Macrophages/ } \\
\text { monocytes }\end{array}$ & $\begin{array}{c}\text { Mast } \\
\text { cells }\end{array}$ \\
\hline Chromogranin A & $\mathrm{r}=0.8$ & $\mathrm{r}=0.7$ & $\mathrm{r}=0.6$ & $\mathrm{r}=0.7$ & $\mathrm{r}=0.8$ & $\mathrm{r}=0.7$ \\
& $\mathrm{P}=0.006$ & $\mathrm{P}=0.009$ & $\mathrm{P}=0.03$ & $\mathrm{P}=0.008$ & $\mathrm{P}=0.0009$ & $\mathrm{P}=0.008$ \\
Serotonin & $\mathrm{r}=0.7$ & $\mathrm{r}=0.7$ & $\mathrm{r}=0.8$ & $\mathrm{r}=0.8$ & $\mathrm{r}=0.8$ & $\mathrm{r}=0.7$ \\
& $\mathrm{P}=0.007$ & $\mathrm{P}=0.004$ & $\mathrm{P}=0.004$ & $\mathrm{P}=0.006$ & $\mathrm{P}=0.004$ & $\mathrm{P}=0.008$ \\
Peptide YY & $\mathrm{r}=0.6$ & $\mathrm{r}=0.6$ & $\mathrm{r}=0.7$ & $\mathrm{r}=0.6$ & $\mathrm{r}=0.7$ & $\mathrm{r}=0.7$ \\
& $\mathrm{P}=0.03$ & $\mathrm{P}=0.04$ & $\mathrm{P}=0.02$ & $\mathrm{P}=0.03$ & $\mathrm{P}=0.02$ & $\mathrm{P}=0.02$ \\
Enteroglucagon & $\mathrm{r}=0.6$ & $\mathrm{r}=0.8$ & $\mathrm{r}=0.8$ & $\mathrm{r}=0.7$ & $\mathrm{r}=0.7$ & $\mathrm{r}=0.9$ \\
& $\mathrm{P}=0.04$ & $\mathrm{P}=0.006$ & $\mathrm{P}=0.006$ & $\mathrm{P}=0.02$ & $\mathrm{P}=0.02$ & $\mathrm{P}=0.0005$ \\
Pancreatic peptide & $\mathrm{r}=-0.7$ & $\mathrm{r}=-0.7$ & $\mathrm{r}=-0.8$ & $\mathrm{r}=0.7$ & $\mathrm{r}=-0.7$ & $\mathrm{r}=0.7$ \\
& $\mathrm{P}=0.006$ & $\mathrm{P}=0.007$ & $\mathrm{P}=0.001$ & $\mathrm{P}=0.01$ & $\mathrm{P}=0.006$ & $\mathrm{P}=0.006$ \\
Somatostatin & $\mathrm{r}=-0.7$ & $\mathrm{r}=-0.6$ & $\mathrm{r}=-0.6$ & $\mathrm{r}=-0.8$ & $\mathrm{r}=-0.5$ & $\mathrm{r}=-0.8$ \\
& $\mathrm{P}=0.01$ & $\mathrm{P}=0.02$ & $\mathrm{P}=0.02$ & $\mathrm{P}=0.0009$ & $\mathrm{P}=0.006$ & $\mathrm{P}=0.0007$ \\
\hline
\end{tabular}

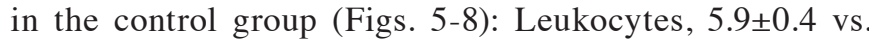
$23.3 \pm 2.2$ cells/field $(\mathrm{P}<0.0001) ; \mathrm{B} / \mathrm{T}$ lymphocytes, $7.8 \pm 0.8$ vs. $23.8 \pm 1.6$ cells/field $(\mathrm{P}<0.0001)$; $\mathrm{T}$ lymphocytes, $6.8 \pm 0.7$ vs. $26.6 \pm 2.9$ cells/field $(\mathrm{P}<0.0001)$; and B lymphocytes, $9.8 \pm 0.6$ vs $22.1 \pm 2.3$ cells/field $(\mathrm{P}<0.0001)$.

Correlation between endocrine and immune cells. The Spearman correlation coefficients and P-values between different endocrine cell types and various immune cells are summarized in Table I. The abnormalities in CgA, serotonin, PYY, and enteroglucagon cells were identified to be positively correlated with the alterations of all types of immune cells, while a negative correlation was observed for PP and somatostatin cells.

\section{Discussion}

Animal models of IBD are either those with chemically induced colitis or mutant (knockout) mice (7,32,36-39). Although neither of these models accurately mimic human IBD, they are useful tools towards understanding the pathophysiological mechanisms underlying IBD (32). DSS-induced colitis is a mixed $\mathrm{Th}_{1} / \mathrm{Th}_{2}$ cytokine-mediated colitis $(40,41)$ and is considered be a model for UC with clinical and morphological features similar to that of human UC $(32,42,43)$. However, DSS-induced colitis lacks the chronicity seen in human UC (32).

The present study identified that the densities of all of the colonic endocrine cell types were affected in rats with DSS-induced colitis. Furthermore, the abnormalities in the colonic endocrine cells were closely correlated with the alterations in several immune-cell types following the induction of colitis. These observations lend support to the hypothesized role of gut hormones in immune activation and inflammation $(30,31,44)$.

CgA belongs to the family of granins $(45,46)$, and is localized to the stomach and small and large intestines (47-50). It is commonly used as a marker for gastrointestinal and endocrine tumor cells $(51,52)$. The increase in $\mathrm{CgA}$-immunoreactive cells observed in the present study could reflect an increase in the cell density of the total colonic endocrine cells following the induction of colitis. This observation is in line with the previously reported increases in CgA cells in UC and CD $(10,23)$. However, $\mathrm{CgA}$ itself inhibits the vascular leakage caused by tumor necrosis factor $\alpha$ (53). Furthermore, CgA-derived peptides reduce the release of interleukin (IL)-16 and IL-5, hence reducing the number of lymphocytes at inflammatory sites and thus the proinflammatory action of lymphocytes and monocytes (54-56). The increase in the density of $\mathrm{CgA}$ cells reported herein was closely associated with the increase in immune cells. Taking into consideration the known interaction between $\mathrm{CgA}$ and immune cells, this increase in $\mathrm{CgA}$ density is likely a response defense mechanism against inflammation.

Serotonin is a potent hormone that exerts several effects at its numerous receptor types. Thus, it stimulates gastric and intestinal motility, modulates visceral sensitivity, and stimulates intestinal secretion $(8,57)$. The present observation of an increased density of colonic serotonin cells in DSS-induced colitis relative to healthy controls is in agreement with previously published observations in patients with UC, CD and MC, and in animal models of colitis (10,12,58-60). However, additional studies identified that the serotonin cell density reduced in UC and remained unchanged in $\mathrm{CD}(61,62)$. It has been reported that serotonin serves an important role in intestinal inflammation $(30,54)$. Thus, the number of serotonin cells has been reported to be reduced in mice lacking the T-lymphocyte receptors (54), IL-13 receptors have been localized on serotonin cells (63), and serotonin receptors have been observed in lymphocytes, monocytes, macrophages and dendritic cells (64). In addition, serotonin affects the proliferation of lymphocytes, protects natural killer cells, inhibits the apoptosis of immune cells, and promotes the recruitment of $\mathrm{T}$ cells (65-68). Thus, the fact that the increase in serotonin-cell 
density in DSS-induced colitis was to be closely associated with the increased densities of the immune-cell types was expected.

PYY and oxyntomodulin are colocalized in the same endocrine cell type $(69,70)$. However, the degree of that colocalization differs according to the animal species (70). PYY delays gastric emptying, and is a key mediator of the ileal brake. It also inhibits gastric and pancreatic secretion, and stimulates the absorption of water and electrolytes (71). Oxyntomodulin has an incretin effect, inhibits gastric and pancreatic secretions, and reduces gastric motility (8). PYY and oxyntomodulin have been previously observed to exhibit anorexigenic effects (72), and the present observation of increased PYY and oxyntomodulin cell densities is in agreement with previous observations in UC and IL-2 gene knockout mice $(10,59)$. Whereas the increase in the oxyntomodulin cell density identified is in line with previous observations in IL-2 knockout mice, it disagrees with observations in UC, where oxyntomodulin cell density was unchanged $(10,59)$. The close correlation between the increase in PYY and oxyntomodulin cell densities with the increase in the densities of the immune cells identified in the current study indicates an interaction between the endocrine and immune systems.

PP stimulates gastric acid secretion and the motility of the stomach and small intestine, and relaxes the gallbladder (8). Somatostatin inhibits intestinal contraction, and gut exocrine and neuroendocrine secretions (8). In addition, somatostatin inhibits lymphocyte proliferation, immunoglobulin synthesis and neutrophil elastase release (73-77). The reduction in PP cell density observed in the present investigation is in line with what has been reported in UC and CD (10). Although the reduction in somatostatin cell density in DSS-induced colitis observed in the current study is also in line with previous publications on UC and CD $(28,29)$, it is in disagreement with a study in which the density of somatostatin cells was observed to be unchanged in these conditions (10). As for the other endocrine cell types assessed in the current study, the correlation between the alterations in the PP and somatostatin cell densities points to their involvement in the inflammatory process.

A potential interaction is suggested between inflammation as indicated by the increase in immune cells and the colonic endocrine cells. It is possible that the increase in serotonin and the reduction in somatostatin cell densities results from inflammation, and that the changes in $\mathrm{CgA}$, PYY, oxyntomodulin and PP cells are secondary responses to the changes in serotonin and somatostatin. Cytokines appear to serve a significant role in the proliferation and differentiation of intestinal stem cells (78-80). It is suggested that inflammation with increased cytokine production increases the serotonin and reduces the somatostatin cell densities by affecting their early progenitors, and that these alterations would result in increased gastrointestinal motility and secretion in addition to visceral hypersensitivity. As a compensatory defense, an increase in PYY and oxyntomodulin, and a reduction in PP would slow gastrointestinal motility and reduce gastrointestinal secretions. The increase in $\mathrm{CgA}$, which appears to have anti-inflammatory effects, may simply reflect the total increase in colonic endocrine cells or another defensive action against inflammation (30).
The induction of colitis by DSS in rats affects all of the colonic endocrine cells. Given the available data on the interactions between hormones and the immune system, it can be hypothesized that inflammation induces the proliferation of serotonin cells and inhibits that of somatostatin cells, in response to which there is a secondary change in the densities of CgA, PYY, oxyntomodulin and PP cells. The close correlation between the changes in all endocrine cell types and immune cells emphasizes the importance of the role of interactions between the intestinal hormone and immune systems in the pathophysiology of intestinal inflammation.

\section{Acknowledgements}

The current study was supported by grants from Helse-Fonna (grant no. 40415), and Helse-Vest (grant no. 911978), Norway.

\section{References}

1. Danese S and Fiocchi C: Etiopathogenesis of inflammatory bowel diseases. World J Gastroenterol 12: 4807-4812, 2006.

2. Nunes T, Fiorino G, Danese S and Sans M: Familial aggregation in inflammatory bowel disease: Is it genes or environment? World J Gastroenterol 17: 2715-2722, 2011

3. El-Salhy M, Gundersen D, Hatlebakk JG and Hausken T: Clinical presentation, diagnosis, pathogenesis and treatment options for lymphocytic colitis (Review). Int J Mol Med 32: 263-270, 2013.

4. Prantera C and Marconi S: Glucocorticosteroids in the treatment of inflammatory bowel disease and approaches to minimizing systemic activity. Therap Adv Gastroenterol 6: 137-156, 2013.

5. Podolsky DK: Inflammatory bowel disease. N Engl J Med 347: 417-429, 2002.

6. Podolsky DK: The current future understanding of inflammatory bowel disease. Best Pract Res Clin Gastroenterol 16: 933-943, 2002.

7. Carter MJ, Lobo AJ and Travis SP; IBD Section, British Society of Gastroenterology: Guidelines for the management of inflammatory bowel disease in adults. Gut 53 Suppl 5: V1-16, 2004

8. El-Salhy M, Seim I, Chopin L, Gundersen D, Hatlebakk JG and Hausken T: Irritable bowel syndrome: The role of gut neuroendocrine peptides. Front Biosci (Elite Ed) 4: 2783-2800, 2012.

9. Wu T, Rayner CK, Young RL and Horowitz M: Gut motility and enteroendocrine secretion. Curr Opin Pharmacol 13: 928-934, 2013.

10. El-Salhy M, Danielsson A, Stenling R and Grimelius L: Colonic endocrine cells in inflammatory bowel disease. J Intern Med 242: 413-419, 1997.

11. El-Salhy M, Gundersen D, Hatlebakk JG and Hausken T: Chromogranin a cell density as a diagnostic marker for lymphocytic colitis. Dig Dis Sci 57: 3154-3159, 2012.

12. El-Salhy M, Gundersen D, Hatlebakk JG and Hausken T: High densities of serotonin and peptide YY cells in the colon of patients with lymphocytic colitis. World J Gastroenterol 18: 6070-6075, 2012.

13. El-Salhy M, Lomholt-Beck B and Gundersen TD: High chromogranin A cell density in the colon of patients with lymphocytic colitis. Mol Med Rep 4: 603-605, 2011.

14. Moran GW, Pennock J and McLaughlin JT: Enteroendocrine cells in terminal ileal Crohn's disease. J Crohns Colitis 6: 871-880, 2012.

15. Moran GW, Leslie FC and McLaughlin JT: Crohn's disease affecting the small bowel is associated with reduced appetite and elevated levels of circulating gut peptides. Clin Nutr 32: 404-411, 2013.

16. Besterman HS, Mallinson CN, Modigliani R, Christofides ND, Pera A, Ponti V, Sarson DL and Bloom SR: Gut hormones in inflammatory bowel disease. Scand J Gastroenterol 18: 845-852, 1983.

17. El-Salhy M, Mazzawi T, Gundersen D, Hatlebakk JG and Hausken T: The role of peptide YY in gastrointestinal diseases and disorders (review). Int J Mol Med 31: 275-282, 2013.

18. Hirotani Y, Mikajiri K, Ikeda K, Myotoku M and Kurokawa N: Changes of the peptide YY levels in the intestinal tissue of rats with experimental colitis following oral administration of mesalazine and prednisolone. Yakugaku Zasshi 128: 1347-1353, 2008.

19. Vona-Davis LC and McFadden DW: NPY family of hormones: Clinical relevance and potential use in gastrointestinal disease. Curr Top Med Chem 7: 1710-1720, 2007. 
20. El-Salhy M, Suhr O and Danielsson A: Peptide YY in gastrointestinal disorders. Peptides 23: 397-402, 2002.

21. Tari A, Teshima H, Sumii K, Haruma K, Ohgoshi H, Yoshihara M, Kajiyama $\mathrm{G}$ and Miyachi Y: Peptide YY abnormalities in patients with ulcerative colitis. Jpn J Med 27: 49-55, 1988.

22. Sciola V, Massironi S, Conte D, Caprioli F, Ferrero S, Ciafardini C, Peracchi M, Bardella MT and Piodi L: Plasma chromogranin a in patients with inflammatory bowel disease. Inflamm Bowel Dis 15: 867-871, 2009.

23. Bishop AE, Pietroletti R, Taat CW, Brummelkamp WH and Polak JM: Increased populations of endocrine cells in Crohn's ileitis. Virchows Arch A Pathol Anat Histopathol 410: 391-396, 1987.

24. Manocha M and Khan WI: Serotonin and GI disorders: An update on clinical and experimental studies. Clin Transl Gastroenterol 3: e13, 2012.

25. Stoyanova II and Gulubova MV: Mast cells and inflammatory mediators in chronic ulcerative colitis. Acta Histochem 104 $185-192,2002$

26. Yamamoto H, Morise K, Kusugami K, Furusawa A, Konagaya T, Nishio Y, Kaneko H, Uchida K, Nagai H, Mitsuma T and Nagura H: Abnormal neuropeptide concentration in rectal mucosa of patients with inflammatory bowel disease. J Gastroenterol 31: $525-532,1996$

27. Payer J, Huorka M, Duris I, Mikulecky M, Kratochvílová H, Ondrejka P and Lukác L: Plasma somatostatin levels in ulcerative colitis. Hepatogastroenterology 41: 552-553, 1994.

28. Watanabe T, Kubota Y, Sawada T and Muto T: Distribution and quantification of somatostatin in inflammatory disease. Dis Colon Rectum 35: 488-494, 1992.

29. Koch TR, Carney JA, Morris VA and Go VL: Somatostatin in the idiopathic inflammatory bowel diseases. Dis Colon Rectum 31: 198-203, 1988.

30. Khan WI and Ghia JE: Gut hormones: Emerging role in immune activation and inflammation. Clin Exp Immunol 161: 19-27, 2010

31. Margolis KG and Gershon MD: Neuropeptides and inflammatory bowel disease. Curr Opin Gastroenterol 25: 503-511, 2009.

32. Elson CO, Sartor RB, Tennyson GS and Riddell RH: Experimental models of inflammatory bowel disease. Gastroenterology 109: 1344-1367, 1995

33. Grimstad T, Bjørndal B, Cacabelos D, Aasprong OG, Omdal R, Svardal A, Bohov P, Pamplona R, Portero-Otin M, Berge RK and Hausken T: A salmon peptide diet alleviates experimental colitis as compared with fish oil. J Nutr Sci 2: e2, 2013.

34. Stucchi AF, Shofer S, Leeman S, Materne O, Beer E, McClung J, Shebani K, Moore F, O'Brien M and Becker JM: NK-1 antagonist reduces colonic inflammation and oxidative stress in dextran sulfate-induced colitis in rats. Am J Physiol Gastrointest Liver Physiol 279: G1298-G1306, 2000.

35. El-Salhy M, Mazzawi T, Umezawa $\mathrm{K}$ and Gilja $\mathrm{OH}$ Enteroendocrine cells, stem cells and differentiation progenitors in rats with TNBS-induced colitis. Int J Mol Med: Oct 24, 2016 (Epub ahead of print).

36. Saleh M and Elson CO: Experimental inflammatory bowe disease: Insights into the host-microbiota dialog. Immunity 34 293-302, 2011.

37. Sands BE: New therapies for the treatment of inflammatory bowel disease. Surg Clin North Am 86: 1045-1064, 2006.

38. Lopez A, Billioud V, Peyrin-Biroulet C and Peyrin-Biroulet L: Adherence to anti-TNF therapy in inflammatory bowel diseases: A systematic review. Inflamm Bowel Dis 19: 1528-1533, 2013.

39. Danese S, Semeraro S, Armuzzi A, Papa A and Gasbarrini A: Biological therapies for inflammatory bowel disease: Research drives clinics. Mini Rev Med Chem 6: 771-784, 2006.

40. Motomura Y, Ghia JE, Wang H, Akiho H, El-Sharkawy RT, Collins M, Wan Y, McLaughlin JT and Khan WI: Enterochromaffin cell and 5-hydroxytryptamine responses to the same infectious agent differ in Th1 and Th2 dominant environments. Gut 57: 475-481, 2008

41. Wirtz S, Neufert C, Weigmann B and Neurath MF: Chemically induced mouse models of intestinal inflammation. Nat Protoc 2: 541-546, 2007.

42. Dieleman LA, Palmen MJ, Akol H, Bloemena E, Peña AS, Meuwissen SG and Van Rees EP: Chronic experimental colitis induced by dextran sulphate sodium (DSS) is characterized by Th1 and Th2 cytokines. Clin Exp Immunol 114: 385-391, 1998.

43. Low D, Nguyen DD and Mizoguchi E: Animal models of ulcerative colitis and their application in drug research. Drug Des Devel Ther 7: 1341-1357, 2013.
44. Öhman L, Tornblom H and Simrén M: Crosstalk at the mucosal border: Importance of the gut microenvironment in IBS. Nat Rev Gastroenterol Hepatol 12: 36-49, 2015

45. Buffa R, Maré P, Gini A and Salvadore M: Chromogranins A and $\mathrm{B}$ and secretogranin II in hormonally identified endocrine cells of the gut and the pancreas. Basic Appl Histochem 32: 471-484, 1988.

46. Eiden LE: Is chromogranin a prohormone? Nature 325: 301, 1987.

47. Buffa R, Capella C, Fontana P, Usellini L and Solcia E: Types of endocrine cells in the human colon and rectum. Cell Tissue Res 192: 227-240, 1978 .

48. Curry WJ, Johnston CF, Hutton JC, Arden SD, Rutherford NG, Shaw $\mathrm{C}$ and Buchanan KD: The tissue distribution of rat chromogranin A-derived peptides: Evidence for differential tissue processing from sequence specific antisera. Histochemistry 96: 531-538, 1991.

49. Portela-Gomes GM and Stridsberg M: Selective processing of chromogranin A in the different islet cells in human pancreas. J Histochem Cytochem 49: 483-490, 2001.

50. Portela-Gomes GM and Stridsberg M: Chromogranin A in the human gastrointestinal tract: An immunocytochemical study with region-specific antibodies. J Histochem Cytochem 50: $1487-1492,2002$

51. Taupenot L, Harper KL and O'Connor DT: The chromogranin-secretogranin family. N Engl J Med 348: 1134-1149, 2003.

52. Wiedenmann B and Huttner WB: Synaptophysin and chromogranins/secretogranins-widespread constituents of distinct types of neuroendocrine vesicles and new tools in tumor diagnosis. Virchows Arch B Cell Pathol Incl Mol Pathol 58: 95-121, 1989.

53. Ferrero E, Magni E, Curnis F, Villa A, Ferrero ME and Corti A Regulation of endothelial cell shape and barrier function by chromogranin A. Ann N Y Acad Sci 971: 355-358, 2002.

54. Spiller R: Serotonin and GI clinical disorders. Neuropharmacology 55: 1072-1080, 2008.

55. Egger M, Beer AG, Theurl M, Schgoer W, Hotter B, Tatarczyk T, Vasiljevic D, Frauscher S, Marksteiner J, Patsch JR, et al: Monocyte migration: A novel effect and signaling pathways of catestatin. Eur J Pharmacol 598: 104-111, 2008

56. Feistritzer C, Mosheimer BA, Colleselli D, Wiedermann CJ and Kahler CM: Effects of the neuropeptide secretoneurin on natural killer cell migration and cytokine release. Regul Pept 126: 195-201, 2005

57. El-Salhy M, Gundersen D, Hatlebakk JG and Hausken T: Irritable bowel syndrome: Diagnosis, pathogenesis and treatment options Nova Science Publishers, Inc., New York, 2012.

58. Bertrand PP and Bertrand RL: Serotonin release and uptake in the gastrointestinal tract. Auton Neurosci 153: 47-57, 2010.

59. Qian BF, El-Salhy M, Melgar S, Hammarstrom ML and Danielsson A: Neuroendocrine changes in colon of mice with a disrupted IL-2 gene. Clin Exp Immunol 120: 424-433, 2000.

60. Oshima S, Fujimura M and Fukimiya M: Changes in number of serotonin-containing cells and serotonin levels in the intestinal mucosa of rats with colitis induced by dextran sodium sulfate Histochem Cell Biol 112: 257-263, 1999.

61. Coates MD, Mahoney CR, Linden DR, Sampson JE, Chen J, Blaszyk H, Crowell MD, Sharkey KA, Gershon MD, Mawe GM and Moses PL: Molecular defects in mucosal serotonin content and decreased serotonin reuptake transporter in ulcerative colitis and irritable bowel syndrome. Gastroenterology 126: 1657-1664, 2004.

62. Sjolund K, Schaffalitzky OB, Muckadell DE, Fahrenkrug J, Håkanson R, Peterson BG and Sundler F: Peptide-containing nerve fibres in the gut wall in Crohn's disease. Gut 24: 724-733, 1983.

63. Wang H, Steeds J, Motomura Y, Deng Y, Verma-Gandhu M, El-Sharkawy RT, McLaughlin JT, Grencis RK and Khan WI: $\mathrm{CD}^{+} \mathrm{T}$ cell-mediated immunological control of enterochromaffin cell hyperplasia and 5-hydroxytryptamine production in enteric infection. Gut 56: 949-957, 2007.

64. Cloëz-Tayarani I and Changeux JP: Nicotine and serotonin in immune regulation and inflammatory processes: A perspective. J Leukoc Biol 81: 599-606, 2007.

65. Stefulj J, Cicin-Sain L, Schauenstein K and Jernej B: Serotonin and immune response: Effect of the amine on in vitro proliferation of rat lymphocytes. Neuroimmunomodulation 9: 103-108, 2001.

66. Betten A, Dahlgren C, Hermodsson S and Hellstrand K: Serotonin protects NK cells against oxidatively induced functional inhibition and apoptosis. J Leukoc Biol 70: 65-72, 2001. 
67. Laberge S, Cruikshank WW, Beer DJ and Center DM: Secretion of IL-16 (lymphocyte chemoattractant factor) from serotonin-stimulated $\mathrm{CD}^{+} \mathrm{T}$ cells in vitro. J Immunol 156: 310-315, 1996.

68. Soga F, Katoh N, Inoue $\mathrm{T}$ and Kishimoto S: Serotonin activates human monocytes and prevents apoptosis. J Invest Dermatol 127: 1947-1955, 2007.

69. Spångéus A, Forsgren S and el-Salhy M: Does diabetic state affect co-localization of peptide YY and enteroglucagon in colonic endocrine cells? Histol Histopathol 15: 37-41, 2000.

70. Pyarokhil AH, Ishihara M, Sasaki M and Kitamura N: The developmental plasticity of colocalization pattern of peptide YY and glucagon-like peptide-1 in the endocrine cells of bovine rectum. Biomed Res 33: 35-38, 2012.

71. El-Salhy M, Gundersen D, Gilja OH, Hatlebakk JG and Hausken T: Is irritable bowel syndrome an organic disorder? World J Gastroenterol 20: 384-400, 2014.

72. El-Salhy M, Gundersen D, Hatlebakk JG and Hausken T: Diet and irritable bowel syndrome, with a focus on appetite-regulating hormones. In: Nutrition in the prevention and treatment of abdominal obesity. Watson RR (ed.) Elsevier, San Diego, pp5-16G, 2014.

73. Payan DG, Hess CA and Goetzl EJ: Inhibition by somatostatin of the proliferation of T-lymphocytes and Molt-4 lymphoblasts. Cell Immunol 84: 433-438, 1984.
74. Adeyemi EO, Savage AP, Bloom SR and Hodgson HJ: Somatostatin inhibits neutrophil elastase release in vitro. Peptides 11: 869-871, 1990.

75. Stanisz AM, Befus D and Bienenstock J: Differential effects of vasoactive intestinal peptide, substance $P$, and somatostatin on immunoglobulin synthesis and proliferations by lymphocytes from Peyer's patches, mesenteric lymph nodes, and spleen. J Immunol 136: 152-156, 1986.

76. Scicchitano R, Dazin P, Bienenstock J, Payan DG and Stanisz AM: Distribution of somatostatin receptors on murine spleen and Peyer's patch T and B lymphocytes. Brain Behav Immun 1: 173-184, 1987.

77. Scicchitano R, Stanisz AM, Payan DG, Kiyono H, McGhee JR and Bienenstock J: Expression of substance P and somatostatin receptors on a T helper cell line. Adv Exp Med Biol 216A: 185-190, 1987.

78. Montgomery RK and Breault DT: Small intestinal stem cell markers. J Anat 213: 52-58, 2008.

79. Potten CS: Stem cells in gastrointestinal epithelium: Numbers, characteristics and death. Philos Trans R Soc Lond B Biol Sci 353: 821-830, 1998.

80. Potten CS: Interleukin-11 protects the clonogenic stem cells in murine small-intestinal crypts from impairment of their reproductive capacity by radiation. Int J Cancer 62: 356-361, 1995. 